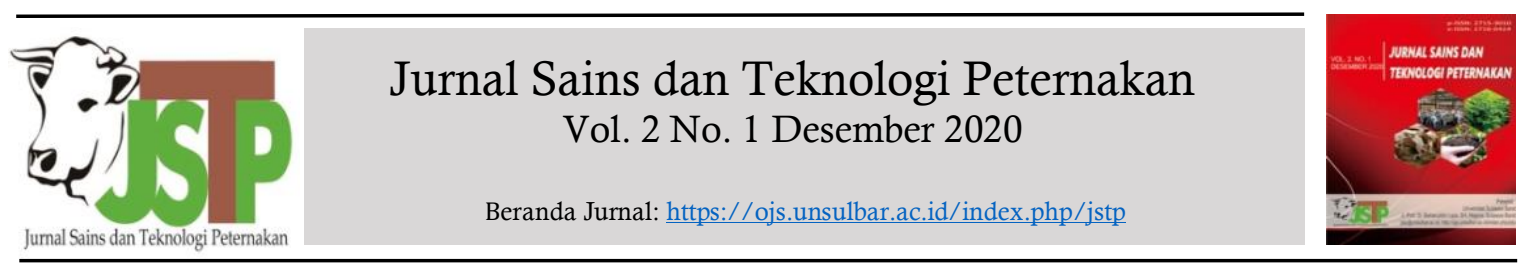

\title{
Pengaruh Waktu Istirahat Berbeda Sebelum Proses Pemotongan Terhadap Respon Suhu Permukaan Tubuh Sapi Brahman Cross
}

(The Effect of Different Preslaughter Resting Periods on Body Surface Temperature Response of Brahman Cross)

\section{Adhyatma ${ }^{1^{*}}$, Gayuh Syaikhullah ${ }^{2}$, dan Himmatul Khasanah ${ }^{3}$}

${ }^{1}$ Program Studi Produksi Ternak, Jurusan Peternakan, Politeknik Negeri Jember.

${ }^{2}$ Program Studi Manajemen Bisnis Unggas, Jurusan Peternakan, Politeknik Negeri Jember. J1. Mastrip 164, Jember, Jawa Timur 68101.

${ }^{3}$ Program Studi Peternakan, Fakultas Pertanian, Univeristas Jember. Jl. Kalimantan No. 38, Kampus Tegal Boto, Jember, Jawa Timur.

\begin{tabular}{l}
\hline A R T I C L E I N F O \\
\hline Received: 11 November 2020 \\
Accepted: 23 Januari 2021
\end{tabular}

${ }^{*}$ Corresponding author m_adhyatma@polije.ac.id

Keywords:

Body surface temperature Brahman cross

Rest periods
Kata Kunci:

Brahman cross

Suhu permukaan tubuh

Waktu istirahat

\begin{abstract}
A B S T R A C T
This study aims to assess the physiological response through body surface temperature of Brahman Cross beef by giving different rest periods. This study used 24 Brahman Cross cattle in several slaughterhouses in West Java. Observation of microclimatic conditions includes temperature, humidity, THI (temperaturehumidity index). Data collections of livestock body surface temperature was carried out when the cattle arrive at the slaughterhouse, while they are in the holding pen and the restraining box. Comparative tests were carried out on the surface temperature of cows under different conditions using a completely randomized design (CRD). This study showed that the body surface temperature was still in the normal range, between $30.89-36.75^{\circ} \mathrm{C}$. Analysis of variance showed that different rest periods had a significant effect $(\mathrm{P}<0.05)$ on body surface temperature change in the eye area in the three pre-cutting stages. Providing a 24 hours rest period resulted in lower stress response in livestock.
\end{abstract}

\begin{tabular}{l}
\hline A B S T R A K \\
Penelitian ini bertujuan untuk mengkaji respon fisiologis melalui \\
suhu permukaan tubuh sapi Brahman cross dengan pemberian \\
waktu istirahat yang berbeda. Sebanyak 24 ekor sapi Brahman Cross \\
yang berada pada beberapa Rumah Potong Hewan di wilayah Jawa \\
Barat digunakan pada penelitian ini. Pengamatan kondisi \\
mikroklimatik meliputi suhu, kelembaban, THI (temperature- \\
humidity index). Pengambilan data suhu permukaan tubuh ternak \\
dilakukan saat sapi tiba di RPH, selama berada dikandang \\
penampungan dan saat berada di dalam restrain box. Uji \\
perbandingan dilakukan pada suhu permukaan tubuh sapi pada \\
kondisi yang berbeda dengan menggunakan Rancangan Acak \\
Lengkap (RAL). Pada penelitian ini menunjukkan bahwa suhu \\
permukaan tubuh sapi masih tergolong normal, pada suhu $30,89-$ \\
$36,75{ }^{\circ} \mathrm{C}$. Hasil analisis ragam menunjukkan bahwa pemberian \\
waktu istirahat yang berbeda memberikan pengaruh nyata $(\mathrm{P}<0,05)$ \\
terhadap perubahan suhu permukaan tubuh area mata pada ketiga \\
tahapan pra pemotongan. Pemberian waktu istirahat 24 jam \\
menghasilkan respon stres pada ternak yang lebih rendah.
\end{tabular} p-ISSN: 2715-3010 | e-ISSN: 2716-0424 


\section{Pendahuluan}

Kebutuhan daging sapi setiap tahun selalu mengalami peningkatan seiring dengan kesadaran konsumen terhadap pentingnya mengonsumsi daging. Alur distribusi daging sapi di Indonesia, dimulai pada proses pemotongan di Rumah Potong Hewan (RPH) hingga dipasarkan ke konsumen dan retail. Oleh sebab itu RPH sebagai unit produksi memiliki peran penting sebagai mata rantai untuk menyuplai daging dengan kualitas yang baik.

Aspek kesejahteraan hewan (animal welfare) perlu diperhatikan pada proses pemotongan ternak di RPH mulai dari penurunan ternak, penanganan selama di kandang penampungan, penggiringan menuju ruang pemotongan hingga proses pemotongan. Proses pra pemotongan hewan dengan penerapan animal welfare dapat mempermudah penanganan ternak dan memperoleh kualitas daging yang ASUH (aman, sehat, utuh, halal) serta aman dikonsumsi masyarakat (Wenno, Swacita, \& Suada, 2015).

Salah satu faktor penting pada saat penanganan ternak selama di kandang penampungan adalah waktu istirahat yang diberikan sebelum ternak dipotong. Menurut Soeparno (2009), istirahat pada ternak adalah proses penanganan ternak sebelum pemotongan dimana ternak didiamkan dalam kandang penampungan sementara, baik dengan ataupun tanpa pemuasaan. Waktu normal yang dibutuhkan untuk mengistirahatkan ternak sebelum pemotongan sekitar 12-24 jam (Anamuli, Detha, \& Wuri, 2016).

Tujuan ternak diistirahatkan sebelum pemotongan agar dapat mengembalikan kondisi fisiologis ternak akibat kelelahan selama transportasi dan menurunkan tingkat stres sehingga dapat mempercepat proses pemotongan serta saat disembelih darah dapat keluar sebanyak mungkin. Selain itu agar tersedia sejumlah glikogen dalam otot yang digunakan sebagai cadangan energi sehingga proses rigormortis dapat berlangsung secara sempurna (Adhyatma, Nuarini, \& Yani, 2017). Kondisi stres merupakan mekanisme modifikasi fisiologis yang merupakan respon dari ternak akibat rangsangan stres (stresor) dengan perubahan homeostasis yang minimum (Efendy, 2018). Kondisi stres pada ternak sebelum pemotongan juga dapat menstimulasi pelepasan hormon kortisol sehingga dapat meningkatkan jumlah konsentrasinya dalam darah yang disertai dengan deplesi glikogen pada otot (Cottle \& Lewis, 2014).

Efek stres pada ternak sebelum proses pemotongan juga dapat mempengaruhi metabolisme otot dimana terjadi pengosongan persediaan glikogen pada otot yang berdampak buruk pada kualitas daging. Keadaan ini mengakibatkan menurunnya kadar asam laktat pada otot dan meningkatkan $\mathrm{pH}$ daging melebihi normal (Authie et al., 2013). Berdasarkan uraian tersebut, dianggap perlu dilakukan pengamatan pada RPH untuk mengetahui respon fisiologis ternak melalui pengamatan suhu permukaan dengan pemberian waktu istirahat yang berbeda sebelum pemotongan agar dapat diketahui berapa lama waktu efektif untuk mengistirahatkan ternak sebelum pemotongan.

\section{Materi dan Metode}

\subsection{Materi Penelitian}

Penelitian ini menggunakan sapi Brahman cross steer yang dipotong pada beberapa $\mathrm{RPH}$ di wilayah Jawa Barat. Alat yang digunakan dalam penelitian ini adalah termometer dry wet, stop watch, Thermal Camera seri A320 (FLIR: USA).

\subsection{Prosedur Penelitian}

Sebanyak 24 ekor sapi Brahman cross steer yang terdiri dari 6 ekor pada masing-masing $\mathrm{RPH}$ yang diberi waktu istirahat berbeda antara 3, 6, 12 dan 24 jam sebelum dilakukan proses pemotongan. Selama sapi di kandang dilakukan pengamatan mikroklimatik meliputi suhu, kelembaban, dan temperature-humidity index (THI). Pengambilan data suhu permukaan tubuh ternak dilakukan saat sapi tiba di RPH, selama berada di kandang penampungan (Gambar 1) dan saat berada di dalam restrain box (Gambar 2).

\subsection{Rancangan Percobaan}

Penelitian ini menggunakan Rancangan Acak Lengkap (RAL) pola faktorial $4 \times 3$ dengan 4 kali ulangan dan tiap ulangan berisi 6 ekor sapi. Faktor pertama adalah waktu istirahat $(3,6,12$ dan 24 jam). Faktor kedua adalah tahapan pra penyembelihan terdiri dari unloading, recovery dan restrain box dari masing-masing $\mathrm{RPH}$. Uji perbandingan dilakukan pada suhu permukaan tubuh sapi dengan kondisi yang berbeda.

\subsection{Peubah yang Diamati}

\section{Faktor Lingkungan}

Suhu udara dan kelembaban diukur dengan termometer bola basah dan bola kering. Pengukuran dilakukan di dalam kandang. Data diambil selama sapi berada dalam kandang 
penampungan. THI dihitung dengan persamaan Hahn (2009) yaitu:

$$
\mathrm{THI}=\mathrm{Tbk}+(0,36 \times \mathrm{Tbb})+41,2
$$

Keterangan:

THI: Temperature Humidity Index,

Tbk: Temperatur bola kering $\left({ }^{\circ} \mathrm{C}\right)$, dan

Tbb: Temperatur bola basah $\left({ }^{\circ} \mathrm{C}\right)$.

\section{Respon Suhu Permukaan Tubuh}

Pengamatan suhu permukaan tubuh dilakukan dengan teknik citra inframerah menggunakan alat FLIR Thermal Camera seri A320 yang dikoneksikan dengan software IR Video Monitor untuk merekam gelombang panas pada objek penelitian. Perekaman suhu permukan tubuh dilakukan sebanyak 3 kali yaitu sesaat setelah sapi turun dari moda transportasi, setelah sapi diistirahatkan, serta saat sapi dimasukkan ke dalam restrain box. Area Pengamatan suhu permukaan tubuh dilakukan pada bagian mata, dahi, mulut, punggung, leher. Rekaman suhu permukaan tubuh sapi kemudian di-capture dan dibuat rataannya menggunakan tools analisys pada software FLIR.

\subsection{Analisis Data}

Data yang diperoleh dianalisis menggunakan analisis ragam (ANOVA). Jika analisis menunjukkan pengaruh nyata terhadap peubah yang diamati, maka dilanjutkan dengan uji lanjut Duncan (Steel \& Torrie, 1991). Analisis dilakukan dengan menggunakan program S.A.S 9.1 .

\section{Hasil dan Pembahasan}

\subsection{Mikroklimatik Lingkungan dan Kandang}

Hasil penelitian menunjukkan rataan suhu lingkungan dan kandang pada RPH III dan IV cenderung lebih tinggi dibandingkan pada RPH I dan II. Kelembaban yang merupakan konsentrasi uap air di udara lebih tinggi pada RPH II dibandingkan ketiga RPH lain. THI merupakan faktor penting yang sangat berpengaruh terhadap kondisi fisiologis ternak. Data kondisi mikroklimat selama penelitian disajikan pada Tabel 1.

Tabel 1. Rataan suhu, kelembaban, dan THI lingkungan dan kandang

\begin{tabular}{lcccc}
\hline \multirow{2}{*}{ Mikroklimat } & \multicolumn{4}{c}{ RPH (waktu istirahat sebelum pemotongan) } \\
\cline { 2 - 5 } & $\begin{array}{c}\text { RPH I } \\
(3 \mathrm{Jam})\end{array}$ & $\begin{array}{c}\text { RPH II } \\
(6 \mathrm{Jam})\end{array}$ & $\begin{array}{l}\text { RPH III } \\
(12 \mathrm{Jam})\end{array}$ & $\begin{array}{c}\text { RPH IV } \\
(24 \text { jam })\end{array}$ \\
\hline Suhu Lingkungan $\left({ }^{\circ} \mathrm{C}\right)$ & $25,17 \pm 1,17$ & $25,83 \pm 0,75$ & $27,67 \pm 0,52$ & $29,17 \pm 2,04$ \\
Suhu Kandang $\left({ }^{\circ} \mathrm{C}\right)$ & $23,33 \pm 1,21$ & $23,33 \pm 0,82$ & $26,50 \pm 0,55$ & $26,83 \pm 1,47$ \\
Kelembaban $(\%)$ & $85,67 \pm 4,76$ & $87,50 \pm 4,28$ & $83,33 \pm 3,27$ & $83,17 \pm 8,06$ \\
THI Lingkungan & $74,95 \pm 1,62$ & $75,85 \pm 1,01$ & $76,81 \pm 1,06$ & $80,15 \pm 2,43$ \\
THI Kandang & $72,45 \pm 1,64$ & $72,57 \pm 1,11$ & $77,95 \pm 1,06$ & $77,27 \pm 1,90$ \\
\hline
\end{tabular}

Keterangan: RPH: Rumah Potong Hewan.

Berdasarkan hasil pengamatan pada keempat kandang penampungan $\mathrm{RPH}$ diketahui bahwa suhu lingkungan dan kandang pada $\mathrm{RPH}$ I dan II relatif lebih rendah dengan kisaran $25^{\circ} \mathrm{C}$ dan $23{ }^{\circ} \mathrm{C}$, namun tidak berbeda nyata. Kondisi ini cukup baik bagi ternak dimana suhu kandang pada proses unloading sapi ke dalam $\mathrm{RPH}$ sangat berpengaruh terhadap proses pemulihan kondisi sapi akibat proses transportasi menuju RPH. Menurut Yousef (1985) suhu yang optimal (comfort zone) bagi ternak produksi di daerah tropis berkisar antara $22-30{ }^{\circ} \mathrm{C}$. Suhu lingkungan pada kisaran comfort zone ternak dapat membantu melancarkan proses fisiologis ternak. Kondisi lingkungan yang buruk dapat menyebabkan stres yang dapat dilihat dari tingkah laku abnormal ternak seperti rasa sakit, ketakutan, dan ketidaknyamanan (Dodzi \& Muchenje, 2011).

Suhu lingkungan pada keempat kandang penampungan berbanding terbalik terhadap kelembaban udara di dalam kandang. Hal ini menunjukkan bahwa uap air yang cukup tinggi di dalam kandang tidak terdistribusi keluar kandang dengan baik. Chase (2013) mengemukakan bahwa kelembaban udara yang cukup tinggi merupakan salah satu faktor penting yang dapat menurunkan tingkat kenyamanan ternak dalam kandang. Tingginya persentase kelembaban diperkirakan akibat jumlah ternak dalam satu pen kandang yang terlalu banyak sehingga menyebabkan terhambatnya sirkulasi udara dari dalam ke luar kandang. Kelembaban udara relatif bagi produksi ternak adalah di bawah $75 \%$ (Yousef, 1985).

Interaksi antara temperatur dan kelembaban udara menghasilkan THI. Dari hasil pengamatan diketahui nilai THI pada kandang RPH III dan IV relatif cukup tinggi. (Nuriyasa, Dewi, \& Budiari (2015) melaporkan bahwa nilai THI pada kandang sapi bali di bawah 73,24 menunjukkan kondisi nyaman bagi ternak. 
Parameter nilai THI dapat dijadikan salah satu indikator tingkat kenyamanan ternak dimana nilai THI yang lebih tinggi dari kisaran optimum menggambarkan makin tinggi tingkat cekaman panas yang dialami ternak (Nuriyasa, 2012).

\subsection{Suhu Permukaan Tubuh}

Tinggi Pengukuran suhu permukaan tubuh dengan metode termografi inframerah (IRT)

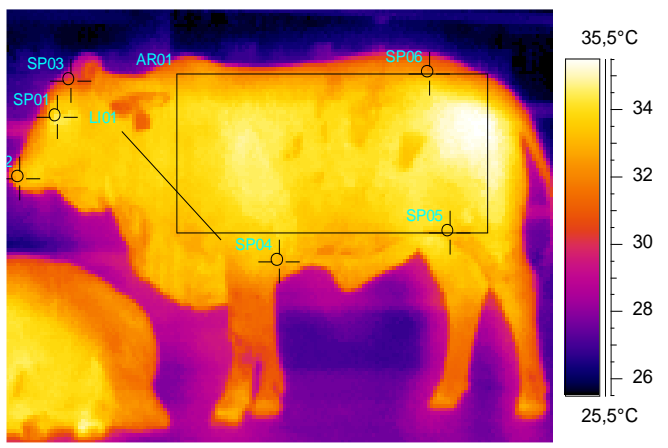

Gambar 1. SPT di kandang merupakan salah satu metode non invasif yang dapat digunakan untuk mengetahui gambaran umum suhu tubuh. (Johnson, Rao, Hussey, Morley, \& Traub-Dargatz (2011) menyatakan bahwa penggunaan IRT untuk mengukur suhu tubuh merupakan metode alternatif yang lebih cepat dan relatif mudah dibandingan metode pengukuran suhu tubuh dengan termometer rektal.

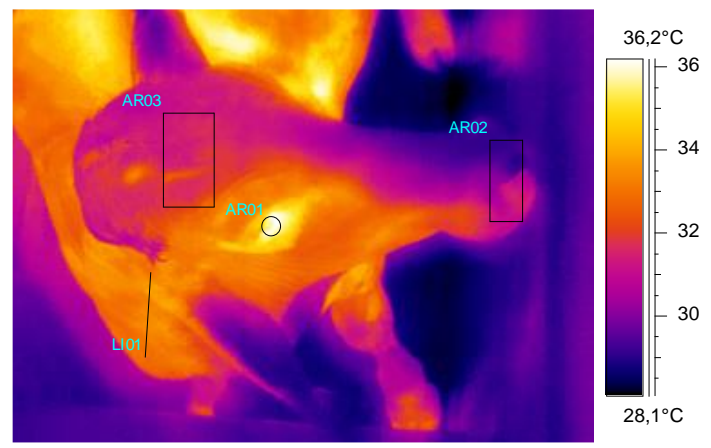

Gambar 2. SPT di restrain box

nilai ratan suhu permukaan tubuh terendah pada area mata, terjadi pada sapi dengan pemberian waktu istirahat 24 jam, sedangkan pada area dahi, mulut, punggung dan leher, suhu terendah ditunjukkan pada sapi dengan waktu istirahat 3 jam. Hasil pengukuran suhu pada area mata, dahi, mulut, punggung dan leher pada sapi Brahman cross disajikan pada Tabel 2.

permukaan tubuh sapi dengan pemberian waktu istirahat yang berbeda sebagian besar masih dalam kisaran normal, yaitu berkisar antar 30,89 $-36,75^{\circ} \mathrm{C}$. Kisaran suhu permukaan tubuh sapi yang dipelihara pada lingkungan mikro yang nyaman sekitar 33,5 - 37,1 ${ }^{\circ} \mathrm{C}$ (Novianti, Purwanto, \& Atabani, 2013). Pada penelitian ini,

Tabel 2. Rataan suhu permukaan tubuh sapi Brahman cross pada area mata, dahi, mulut, punggung dan leher dengan pemberian waktu istirahat yang berbeda

\begin{tabular}{|c|c|c|c|c|c|}
\hline \multirow{2}{*}{ Area } & \multirow{2}{*}{$\begin{array}{c}\text { Waktu } \\
\text { Istirahat }\end{array}$} & \multicolumn{3}{|c|}{ Tahapan pra Penyembelihan } & \multirow{2}{*}{ Rataan } \\
\hline & & Unloading & Recovery & Restrain & \\
\hline \multirow{5}{*}{ Mata } & 3 & $35,28 \pm 0,18$ & $35,20 \pm 0,38$ & $37,47 \pm 0,49$ & $36,75 \pm 0,56^{\mathrm{a}}$ \\
\hline & 6 & $36,00 \pm 0,60$ & $35,87 \pm 0,31$ & $37,25 \pm 0,78$ & $36,37 \pm 0,76^{\mathrm{ab}}$ \\
\hline & 12 & $37,38 \pm 0,39$ & $36,32 \pm 0,64$ & $36,55 \pm 0,55$ & $35,98 \pm 1,29 \mathrm{bc}$ \\
\hline & 24 & $37,22 \pm 1,53$ & $34,27 \pm 0,88$ & $35,02 \pm 1,05$ & $35,50 \pm 1,53^{c}$ \\
\hline & Rataan & $36,47 \pm 1,00^{\mathrm{a}}$ & $35,42 \pm 0,89^{b}$ & $36,57 \pm 1,11^{\mathrm{a}}$ & \\
\hline \multirow{5}{*}{ Dahi } & 3 & $31,92 \pm 1,48$ & $31,27 \pm 2,00$ & $30,58 \pm 1,91$ & $31,26 \pm 0,67^{\mathrm{a}}$ \\
\hline & 6 & $33,27 \pm 1,87$ & $32,80 \pm 2,48$ & $32,72 \pm 3,41$ & $32,60 \pm 0,29^{b}$ \\
\hline & 12 & $36,15 \pm 0,64$ & $35,47 \pm 0,73$ & $35,22 \pm 0,76$ & $35,61 \pm 0,48^{c}$ \\
\hline & 24 & $36,17 \pm 1,65$ & $31,85 \pm 1,40$ & $33,10 \pm 2,09$ & $33,71 \pm 2,22^{\mathrm{b}}$ \\
\hline & Rataan & $34,38 \pm 2,35^{\mathrm{a}}$ & $32,85 \pm 1,86^{b}$ & $32,91 \pm 1,90^{b}$ & \\
\hline \multirow{5}{*}{ Mulut } & 3 & $31,07 \pm 1,73$ & $30,42 \pm 2,72$ & $31,35 \pm 2,06$ & $30,89 \pm 0,66^{\mathrm{a}}$ \\
\hline & 6 & $32,52 \pm 2,06$ & $31,82 \pm 3,22$ & $32,53 \pm 3,45$ & $32,29 \pm 0,41^{\mathrm{ab}}$ \\
\hline & 12 & $36,03 \pm 0,38$ & $35,43 \pm 0,74$ & $35,12 \pm 1,02$ & $35,53 \pm 0,46^{c}$ \\
\hline & 24 & $35,73 \pm 1,37$ & $32,80 \pm 0,57$ & $32,08 \pm 2,02$ & $33,54 \pm 1,93^{b}$ \\
\hline & Rataan & $34,76 \pm 1,95$ & $32,62 \pm 2,11$ & $32,77 \pm 1,64$ & \\
\hline \multirow{5}{*}{ Punggung } & 3 & $31,88 \pm 1,16$ & $30,95 \pm 1,82$ & $32,32 \pm 1,76$ & $31,72 \pm 0,70^{\mathrm{a}}$ \\
\hline & 6 & $33,65 \pm 1,76$ & $33,20 \pm 3,04$ & $32,67 \pm 2,01$ & $33,17 \pm 0,49^{b}$ \\
\hline & 12 & $36,28 \pm 0,50$ & $36,30 \pm 0,70$ & $35,85 \pm 0,62$ & $36,14 \pm 0,25^{\mathrm{c}}$ \\
\hline & 24 & $36,28 \pm 1,59$ & $32,50 \pm 1,19$ & $33,62 \pm 1,38$ & $34,14 \pm 1,94^{\mathrm{b}}$ \\
\hline & Rataan & $34,53 \pm 2,15^{\mathrm{a}}$ & $33,24 \pm 2,25^{b}$ & $33,61 \pm 1,59^{b}$ & \\
\hline \multirow{5}{*}{ Leher } & 3 & $34,95 \pm 0,16$ & $33,17 \pm 1,81$ & $33,23 \pm 1,82$ & $33,78 \pm 1,01^{\mathrm{a}}$ \\
\hline & 6 & $35,45 \pm 0,55$ & $34,85 \pm 1,33$ & $33,93 \pm 1,51$ & $34,74 \pm 0,77^{\mathrm{b}}$ \\
\hline & 12 & $36,25 \pm 0,44$ & $35,68 \pm 0,66$ & $35,63 \pm 0,48$ & $35,86 \pm 0,34^{\mathrm{c}}$ \\
\hline & 24 & $36,53 \pm 1,28$ & $33,82 \pm 0,51$ & $33,95 \pm 1,45$ & $34,77 \pm 1,53^{\mathrm{b}}$ \\
\hline & Rataan & $35,80 \pm 0,73^{a}$ & $34,38 \pm 1,11^{\mathrm{b}}$ & $34,19 \pm 1,02^{b}$ & \\
\hline
\end{tabular}

Keterangan: Superskrip pada kolom yang sama menunjukkan perbedaan yang nyata pada taraf uji $5 \%$. 
Berdasarkan analisis ragam menunjukkan bahwa pemberian waktu istirahat yang berbeda memberikan pengaruh nyata $(\mathrm{P}<0,05)$ terhadap perubahan suhu permukaan tubuh area mata pada ketiga tahapan pra penyembelihan. Berdasarkan kelima area pengamatan suhu permukaan tubuh, sapi yang diberi waktu istirahat 24 jam menunjukkan peningkatan suhu dari tahapan recovery hingga sapi dimasukkan ke dalam restrain box yang lebih rendah dibandingkan ketiga perlakuan lainnya. Nilai rataan suhu area mata pada sapi dengan waktu istirahat 24 jam sebesar $35,50^{\circ} \mathrm{C}$. Nilai ini tidak jauh berbeda dengan yang dilaporkan oleh Cardoso et al. (2015) dimana sapi yang dipelihara pada kondisi lingkungan dan penanganan optimal memiliki suhu pada area mata sekitar $34,73-35,88^{\circ} \mathrm{C}$.

Nilai rataan suhu area dahi, mulut, punggung dan leher pada ternak yang diberi istirahat 3 dan 6 jam cenderung lebih rendah dibandingkan dengan ternak yang diberi waktu istirahat 12 dan 24 jam. Hal ini disebabkan oleh pemberian waktu istirahat yang lebih singkat sehingga ternak belum dapat beradaptasi dengan kondisi lingkungan kandang, sehingga proses vasoliditasi dimana pada saat suhu tinggi, pembuluh darah akan mengembang untuk berdekatan dengan kulit yang memungkinkan panas tersalurkan keluar tubuh. Pelepasan panas dari dalam tubuh diatur oleh perubahan jumlah darah yang mengalir melalui kulit. Rangsangan panas atau dingin akan diterima kulit kemudian dihantarkan ke susunan syaraf pusat dan diteruskan ke hipotalamus bagian pre optic (Ganong, 2005).

Temperatur permukaan kulit ternak sangat dipengaruhi oleh kondisi iklim makro lokasi peternakan. Marcillac-Embertson, Robinson, Fadel, \& Mitloehner (2009) mengemukakan bahwa kulit sangat berkorelasi terhadap kadar uap air lingkungan, lokasi kandang serta fluktuasi cuaca karena merupakan bagian yang mengalami kontak langsung.

Suhu permukaan tubuh pada kelima area pengamatan mengalami penurunan dari tahapan unloading hingga setelah pemulihan (recovery). Suhu permukaan area mata setelah tahapan recovery memiliki korelasi terhadap permberian waktu istirahat. Ternak dengan pemberian waktu istirahat 3 jam menunjukkan penurunan suhu paling rendah $\left(35,20{ }^{\circ} \mathrm{C}\right)$ sedangkan dengan pemberian istirahat 24 jam terjadi penurunan suhu sebesar $34,27^{\circ} \mathrm{C}$. Penurunan suhu tersebut disebabkan oleh waktu adaptasi terhadap kondisi lingkungan yang lebih panjang sehingga ternak mampu melakukan mekanisme homeostasis dengan baik dimana tubuh akan mengeluarkan keringat lebih sedikit dan mempersempit pembuluh darah (vasokonstriksi) sehingga mengurangi pengeluaran panas tubuh (Jaddoa, Al-Jumaily, Gonzalez, \& Cuthbertson, 2017).

Pada saat sapi berada pada restrain box, terjadi peningkatan suhu area mata yang cukup tinggi dengan pemberian waktu istirahat 3 dan 6 jam dibanding sapi dengan waktu istriahat 12 dan 24 jam. Kenaikan suhu tersebut disebabkan oleh stres yang dialami ternak berupa tekanan psikologis saat ternak dipisahkan dari kelompok untuk digiring melewati gangway menuju restrain box. Saat ternak mengalami stres, hypotalamus pituitary adrenal (HPA) aksis akan aktif untuk meproduksi panas yang diakibatkan oleh meningkatnya kadar katekolamin dan kortisol dalam darah. Ekspresi panas yang dihasilkan tubuh dapat tertangkap oleh alat IRT dalam bentuk gambar tanpa perlu melakukan kontak dengan ternak. Hasil penelitian Jaddoa et al. (2017) menujukkan adanya korelasi yang signifikan antara suhu maksimum mata dengan kadar kortisol saliva serta aktivitas HPA aksis.

\section{Kesimpulan}

Peningkatan suhu permukaan tubuh pada seluruh area pengamatan dari tahapan recovery hingga ternak dimasukkan ke dalam restain box yang paling rendah ditunjukkan pada ternak yang diberi waktu istirahat 24 jam sebelum proses pemotongan. Pemberian waktu istirahat 24 jam menghasilkan respon stres pada ternak yang lebih rendah.

\section{Daftar Pustaka}

Adhyatma, M., Nuarini, N., \& Yani, A. (2017). Proses eksanguinasi dan kualitas fisik daging sapi Brahman cross dengan waktu istirahat berbeda sebelum pemotongan. Jurnal Ilmu Produksi dan Teknologi Hasil Peternakan, 5(3), 106-109. https://doi.org/ 10.29244/jipthp.5.3.106-109

Anamuli, E. R. B., Detha, A. I. R., \& Wuri, D. A. (2016). Pengaruh faktor pengistirahatan ternak sebelum pemotongan terhadap kualitas daging sapi di rumah potong hewan Oeba berdasarkan nilai $\mathrm{pH}$ dan daya ikat air. Jurnal Veteriner Nusantara, 1(1), 21-33.

Authie, E., Berg, C., Bøtner, A., Browman, H., Capua, I., Koeijer, A. A. de, ... Zientara, S. (2013). Scientific opinion on monitoring procedures at slaughterhouses for bovines. EFSA Journal, 11(12), 1-65. https://doi.org $/ 10.2903 /$ j.efsa. 2013.3460

Cardoso, C. C., Peripolli, V., Amador, S. A., 
Brandão, E. G., Esteves, G. I. F., Sousa, C. M. Z., ... McManus, C. (2015). Physiological and thermographic response to heat stress in Zebu cattle. Livestock Science, 182, 83-92. https://doi.org/10. 1016/j.livsci.2015.10.022

Chase, L. E. (2013). Climate change impacts on dairy cattle. In Climate Change and Agriculture: Promoting Practical and Profitable Responses. Retrieved from https:// www.researchgate.net /profile/LarryChase/publication/253292665_Climate_C hange_Impacts_on_Dairy__Cattle/ links /54179b670cf2f48c74a40d0c/ ClimateChange-Impacts-on-Dairy-Cattle.pdf

Cottle, D. J., \& Lewis, K. (2014). Beef Cattle Production and Trade (D. J. Cottle \& K. Lewis, Eds.). Collingwood Australia: CSIRO Publishing. https://doi.org/10. 1071/9780643109896

Dodzi, M. S., \& Muchenje, V. (2011). Avoidance-related behavioural variables and their relationship to milk yield in pasture-based dairy cows. Applied Animal Behaviour Science, 133(1-2), 11-17. https:// doi.org/10.1016/j.applanim.2011.04.014

Efendy, J. (2018). Aktivitas harian dan deteksi stres pada sapi Peranakan Ongole (PO). MADURANCH: Jurnal Ilmu Peternakan, 3(2), 53-58.

Ganong, W. F. (2005). Review of Medical Physiology. Newyork: McGraw-Hill.

Hahn, G. L., Gaughan, J. B., Mader, T. L., \& Eigenberg, R. A. (2009). Thermal indices and their applications for livestock environments. In J. A. DeShazer (Ed.), Livestock Tnergetics and thermal Environment Management (pp. 113-130). Michigan: American Society of Agricultural and Biological Engineers.

Jaddoa, M. A., A1-Jumaily, A., Gonzalez, L., \& Cuthbertson, H. (2017). Automatic eyes localization in thermal images for temperature measurement in cattle. Proceedings of the 2017 12th International Conference on Intelligent Systems and Knowledge Engineering (ISKE) 2017, 1-6. Nanjing: IEEE. https://doi.org/10.1109/ ISKE.2017.8258765

Johnson, S. R., Rao, S., Hussey, S. B., Morley, P. S., \& Traub-Dargatz, J. L. (2011). Thermographic eye temperature as an index to body temperature in Ponies. Journal of Equine Veterinary Science, 31(2), 63-66. https://doi.org/10.1016/j.jevs.
2010.12.004

Marcillac-Embertson, N. M., Robinson, P. H., Fadel, J. G., \& Mitloehner, F. M. (2009). Effects of shade and sprinklers on performance, behavior, physiology, and the environment of heifers. Journal of Dairy Science, 92(2), 506-517. https://doi.org/10. 3168/jds.2008-1012

Novianti, J., Purwanto, B. P., \& Atabani, A. (2013). Respon fisiologis dan poduksi susu sapi perah $\mathrm{FH}$ pada pemberian rumput gajah (Pennisetum purpureum) dengan ukuran pemotongan yang berbeda. Jurnal Ilmu Produksi dan Teknologi Hasil Peternakan, 1(3), 138-146. https://doi.org/10.29244/ jipthp.1.3.138-146

Nuriyasa, I. M. (2012). Respon biologi serta pendugaan kebutuhan energi dan protein terrnak kelinci (Lepus nigricollis) pada kondisi lingkungan berbeda di daerah dataran rendah tropis. Universitas Udayana.

Nuriyasa, I. M., Dewi, G. A. M. K., \& Budiari, N. L. G. (2015). Indeks kelembaban suhu dan respon fisiologi sapi Bali yang dipelihara secara feed lot pada ketinggian berbeda. Majalah Ilmiah Peternakan, 18(1), 5-10. https://doi.org/10.24843/mip.2015. v18.i01.p02

Soeparno. (2009). Ilmu dan Teknologi Daging. Yogyakarta: Gajah Mada University Press.

Steel, R. G. D., \& Torrie, J. H. (1991). Prinsib dan Prosedur Satistika: Suatu Pendekatan Biometrik (Bambang Sumantri, Ed.). Jakarta: Gramedia Pustaka Utama.

Wenno, C. R. F., Swacita, I. B. N., \& Suada, I. K. (2015). Penerapan animal welfare pada proses pemotongan sapi Bali di rumah pemotongan hewan Pesanggaran, Denpasar Bali. Indonesia Medicus Veterinus, 4(3), 238-248. https://doi.org/10.1007/ s40618-015-0383-7

Yousef, M. K. (1985). Stress Physiology in Livestock. Boca Raton, Florida, USA: CRC Press. 